\title{
NGHIÊN CỨU ĐẶC ĐIỂM LÂM SÀNG UNG THƯ KHOANG MIỆNG
}

\section{TÓM TẮT}

Muc tiêu: Nhân xét về đặc điểm lâm sàng ung thư khoang miệng. Đối tượng và phương pháp: nghiên cứu mô tả cắtngang trên 61 bệnh nhân đến ung thư khoang miệng trong giai đoạn từ 2014 đến 2020 tai bênh viên Răng Hàm Măt Tư và bênh viên Trung Ương Quân đội 108, ghi nhận các thông tin về tuổi, giới, hình thái, vị trí và giai đoạn bệnh, các triệu chứng lâm sàng. Kết quả: Tỷ lệ nam, nữ là $3 / 1$, độ tuổi hay gặp từ 50 đến 60 tuổi. Về tế bào học, ung thư tế bào vảy chiếm $100 \%$. Bệnh phát hiện chủ yếu ở giai đoan II và giai đoan III, chiếm tỷ lể $60,65 \%$ và $26,22 \%$, không có bênh nhân tới khám ở giai đoan I. Hinh thái u chủ yếu là thể loét $45.90 \%$ và thể sùi $40.98 \%$, thể thâm nhiễm chỉ chiếm $13.11 \%$. Các triêuu chứng lâm sàng thường gặp là đau chiếm $85,2 \%$, tăng tiết nước bọt - 65,6\%, loét lâu liền -63,9\%. Kết luâan: Ung thư khoang miệng là bệnh lý ác tính vùng hàm măt, thường được phát hiện ở giai đoan muộn do các dẩu hiệuban đầu thường mờ nhạt và ít được bệnh nhân và bác sĩ quan tâm. Do vậy cần khám xét sớm và kỹ lưỡng để phát hiện sớm ung thư giúp điều trị thuân lợi và hiệu quả.

Tư khóa: Ủng thư khoang miệng

\section{SUMMARY}

CLINICAL SYMPTOMS OF ORAL CAVTTY CANCER

Objectives: Commenting on the clinical symptoms of patients with oral cavity cancer in National Hospital ofOdonto-Stomatology Hospital, Hanoi and National Military Hospital 108. Subjects and methods: descriptive study of 61 patient records that are diagnosed with of oral cavity cancer from 2014 to 2020, recording information on age, gender, morphology, location and stage of the disease, clinical symptoms. Results: The gender ratio male/female is $3 / 1$, the most common age is 50 to 60 years old. Squamous cell carcinoma accounts for $100 \%$, of which mainly in stage II and stage III, accounting for $60,65 \%$ and $26,22 \%$. The common clinical symptoms are pain was seen in $-76.91 \%$, increased salivation $65,6 \%$ and necrotic ulcer - 63,9\%. Conclusions: Oral cavity cancer is a severe disease, often detected at an advanced stage. The typical signs need to be paid attention and detected early so that the treatment is more convenient and effective.

Key words: Oral cavity cancer

\section{I. ĐẶT VẤN ĐỀ}

Ung thư khoang miệng đứng thứ 6 trong các

*Bênh viện $R H M$ Trung ương HNi

**Viên Đào tao RHM, ĐHYHN

Chịu trách nhiệm chính: Nguyễn Hồng Nhung

Email: dr.rosy245@gmail.com

Ngày nhận bài: 2/11/2021

Ngày phản biên khoa họ: 2/12/2021

Ngày duyệt bài: 22/12/2021

\section{Nguyễn Hồng Nhung*, Lê Văn Sơn**}

bệnh ung thư phổ biến hay gặp [1]. Năm 2018, trên toàn thế giới có hơn 117000 người tử vong vì ung thư khoang miệng, $90 \%$ trong số đó là ung thư biểu mô vảy.Tại Mỹ mỗi năm có hơn 30000 ca bệnh mới, trong đó có khoảng 7000 người tử vong vì ung thư khoang miệng. Ung thư biểu mô khoang miệng thường gặp nhiêu nhất ở lưỡi, sàn miệng, sau đó là vùng lợi hàm, môi và niêm mạc má. Ung thư khoang miệng có thể gặp ở các biểu mô quanh răng hoăcc từ chính xương hàm trên và xương hàm dưới. Do đặcđiểm vể cấu trúc, vị trí giải phẫu của vùng hàm mă̆t phức tạp nên các triệu chứng lâm sàng đẩu tiên thường mờ nhạt, thậm chí bệnh nhân và thầy thuốc không đểý, dấu hiệu đau thường đến muộn do vậy những khối u được phát hiệnở giai đoạn muộn nên tỷ lệ sống sót của ung thư khoang miệng hầu như không thay đổi trong suốt 30 năm qua, cho dù y học vẫn ngày một phát triển [2]. Tại Việt Nam, ô nhiếm mồi trường, thực phẩm có tồn dư hóa chất... làm cho tỷ lệ mắc ung thư hàm mặt gia tăng, đa số bệnh nhân được phát hiệnở giai đoạn muộn gây ảnh hưởng đển hiệu quả điều trị. Do vậy, chúng tôi tiến hành đề tài này nhằm đưa ra những nhận xét về đặc điểm lâm sàng ung thư khoang miệng để từ đó có thể đề xuất các giải pháp phù hợp trong chẩn đoán và điều trị bệnh lý này.

\section{II. ĐỐl TƯƠNNG VÀ PHƯƠNG PHÁP NGHIÊN CỨU}

2.1. Đối tượng nghiên cứu: Tất cả các bệnh nhân đến khám và có kết quả chẩn đoán làung thư khoang miệng.

2.2. Phương pháp nghiên cứu:Nghiên cứu mô tả cắt ngang được thực hiện trên 61 bệnh nhân đã được chẩn đoánvà điều trị ung thưkhoang miệngtạibệnh viện Răng Hàm Mặt TW $H N$ và bệnh viện Quân đội TW 108 từ tháng 10/2014 đến tháng 10/2020.

Tiêu chuấn lựa chọn:

- Hồ sơ bệnh ánlưu trữ đầyđủ thông tin cần thiết cho nghiên cứu.

- Chẩnđoánbệnh dựa trên triệu chứng lâm sàng và cận lâm sàng.

- Có kểt quả giải phẫu bệnh.

Tiêu chuấn loại trừ:

- Các trường hợp mô bệnh học thuộc loại ung thư di căn từ nơi khác đến

- Các loại u lành tính của vùng hàm mặt, các khối u vòm, Amydal, u ống tai ngoài hoặc tai giữa. 
Thông tin của tất cả bệnh nhân nghiên cứu được ghi nhận vào phiếu nghiên cứu được thiết kế trước về: tuổi, giới, tiền sử bản thân, thời gian pháthiện bệnh, các thông tin về triệu chứng lâm sàng như tình trạng toàn thân, vị trí và tính chất của khối u, vị trí và tính chất của hạch, các biểu hiện của di căn xa cùng với các xét nghiệm cận lâm sàng như chụp cắt lớp vi tính, kết quả giải phẫu mô bệnh học.

Số liệu thu nhập được xử lý bằng phần mềm SPSS 16.0.

\section{KẾT QUẢ NGHIÊN CỨU \\ 3.1.Đặc điểm về giới tính:}

Đặc điểm giới

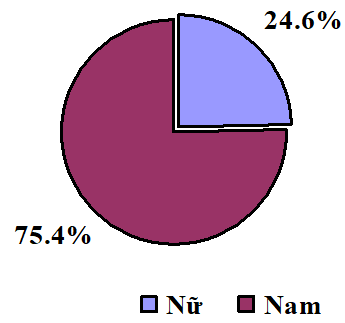

Biểu đồ 3.1. Đặc điểm giới tính ( $n=61$ )

Nhận xét: Số lượng nam mắc ung thư khoang miệng là 46 bệnh nhân, chiếm $75.4 \%$; nữ là 15 bệnh nhân, chiếm $24.6 \%$. Tỷ lệ mắc bệnh giữa bệnh nhân nam trên bệnh nhân nữ tương đương $3 / 1$.

\section{2. Đặc điểm về tuổi:}

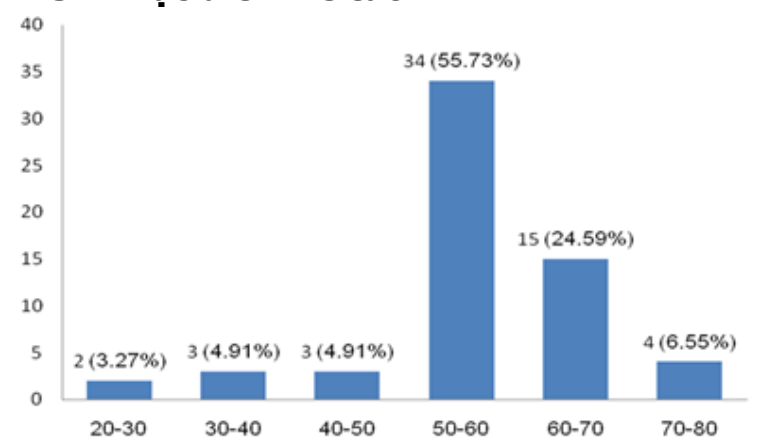

Biểu đồ 3.2. Tuổi và tần xuât mắc bệnh( $n=61)$

Nhận xét: bênh nhân trẻ tuổi nhất là 23 tuổi, bệnh nhân lớn tuổi nhất là 73 tuổi, trung bình $52.16 \pm 10.18$ tuổi. Bệnh nhân dưới 40 tuổi chiếm $8.18 \%$, độ tuổi 50 đến 60 chiếm nhiều nhất $55.73 \%$.

3.3. Liên quan đến yếu tố nguy cơ:

Bảng 3.1: Liên quan yếu tố nguy cơ $(n=61)$

\begin{tabular}{|c|c|c|c|}
\hline \multirow[b]{2}{*}{$\begin{array}{c}\text { Các yếu tố } \\
\text { nguy cơ }\end{array}$} & \multicolumn{2}{|c|}{ Bệnh nhân } & \multirow{2}{*}{$\begin{array}{l}\text { Tổng } \\
\text { (tỷ lệ) }\end{array}$} \\
\hline & $\underset{(n=46)}{N a m}$ & & \\
\hline & & & \\
\hline
\end{tabular}

\begin{tabular}{|c|c|c|c|}
\hline Uống rượu & $5(10.86 \%)$ & 0 & $5(8.2 \%)$ \\
\hline $\begin{array}{c}\text { Hút thuốc }+ \\
\text { Rượu }\end{array}$ & 29 & 0 & 29 \\
$(63.04 \%)$ & 0 & $(47.5 \%)$ \\
\hline Nhai trầu & 0 & $3(20.0 \%)$ & $3(4.9 \%)$ \\
\hline $\begin{array}{c}\text { Không thuốc, } \\
\text { rượu }\end{array}$ & $4(8.69 \%)$ & 12 & 16 \\
\hline Tống & $46(100 \%)$ & $15(100 \%)$ & $(26.2 \%)$ \\
\hline
\end{tabular}

Nhân xét: Tỷ lê bệnh nhân ung thư khoang miệng liên quan đến hút thuốc, uống rượu và nhai trầu là $73.8 \%$ cao hơn nhiêu so với không nghiện là $26.2 \%$. Trong hầu hết các bệnh nhân nam, $91.31 \%$ liên quan đến rượu và thuốc lá, chỉ có $8.69 \%$ không hút thuốc và uống rượu.

\subsection{Các dấu hiệu lâm sàng:}

Bảng 3.2. Các dâu hiệu lâm sàng $(n=61)$

\begin{tabular}{|c|c|c|}
\hline $\begin{array}{c}\text { Các dấu hiệu lâm } \\
\text { sàng }\end{array}$ & $\begin{array}{c}\text { Số } \\
\text { lượng }\end{array}$ & $\begin{array}{c}\text { Tỷ lệ } \\
(\mathbf{\%})\end{array}$ \\
\hline Đau, rát & 52 & 85.2 \\
\hline Tăng tiết nước bọt & 40 & 65.6 \\
\hline Vết loét lâu liền & 39 & 63.9 \\
\hline Điếm sùi vướng & 35 & 57.37 \\
\hline Chảy máu & 17 & 27.9 \\
\hline Miệng hôi & 41 & 67.21 \\
\hline Khó nhai nuốt & 39 & 63.93 \\
\hline
\end{tabular}

Nhân xét: Đau, rát và tăng tiết nước bọt là những dấu hiệu bất thường sớm làm bệnh nhân chú ý, chiếm lần lượt $85.2 \%$ và $65.6 \%$; Vết loét lâu liền, điểm sùi vướng cũng làm bệnh nhân khó chịu, chiếm $63.9 \%$ và $57.37 \%$.

\subsection{Hình thái u}

Bảng 3.3. Hinh thái u $(n=61)$

\begin{tabular}{|c|c|c|}
\hline Hình thái u & Số lượng & Tỷ lệ (\%) \\
\hline Loét & 28 & 45.90 \\
\hline Sùi & 25 & 40.98 \\
\hline Thâm nhiềm & 8 & 13.11 \\
\hline Tống & 61 & 100 \\
\hline
\end{tabular}

Nhân xét: Hình thái u chủ yếu là thể loét 45. $90 \%$ và thể sùi $40.98 \%$, thể thâm nhiễm chỉ chiếm $13.11 \%$.

3.6.Đăcc điểm giải phẫu bệnh. Kết quả giải phẫu bệnh $100 \%$ các trường hợp đều là ung thư biểu mố tế bào vảy.

3.7. Đặc điểm giai đoạn bệnh

o _ Giai đoạn bệnh

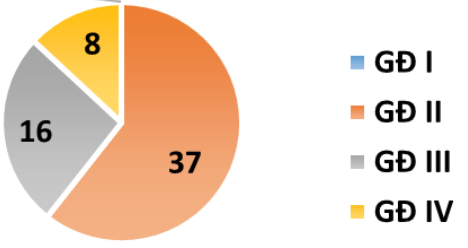

Biểu đồ 3.3. Giai đoạn bệnh 
Nhận xét: Số lượng bệnh nhân ở giai đoạn II của bệnh là $60.65 \%$, giai đoạn III, IV lần lượt là $26.22 \%$ và $13.12 \%$. Không có bệnh nhân nào tới khám khi ở giai đoạn I. Điều này cho thây các bệnh nhân thường tới khám và điều trị muộn.

\section{BÀN LUÂ̂N}

Tiến hành nghiên cứu trên 61 bệnh nhân ung thư khoang miệng đến khám và điều trị tại Bệnh viện Răng Hàm Mặt TW HN và Bệnh viện Quân Đội TW108 trong giai đoạn từ tháng 10/2014 đển tháng 10/2020, chúng tôi nhận thấybệnh nhân có độ tuổi từ 23 đến 73 tuổi, trung bình $52.16 \pm 10.18$ tuổi, hay gặp nhất là từ 50 đến 70 tuổi, chiếm $80,32 \%$. Xu hướng mắc bệnh ở người trẻ tuổi đang gia tăng, có $8,18 \%$ bệnh nhân độ tuổi dưới 45 tuổi.Về độ tuổi mắcung thư khoang miệng trên thế giới có sự dao động giữa các tác già, từ 50 đến 80 tuổi là lứa tuổi thường gặp nhiều nhất. Theo Waseem Jerjes (2010) lứa tuổi trung bình mắc ung thư khoang miệng ở Mỹ là 62 tuổi[3], nghiên cứu của Song X (2010) có độ tuổi trung bình ung thư khoang miệng là 51 tuổi[4]. Điều này phù hợp với nhận xét của các giả trên thế giới về xu hướng gia tăng bệnh ở người trẻ tuổi.

Trong nghiên cứu của chúng tôiung thư khoang miệng thường hay gặp ở nam giới nhiều hơn ở nữ giới do nam giới có thói quen không lành mạnh như uống rượu và hút thuốc. Theo King và cộng sự năm 2010 [5] hút thuốc có liên quan tới tổn thương ung thư và tiền ung thư khoang miệng, người hút thuốc dưới 5 điếu/ngày có nguy cớ tổn thương tiên ung thư và ung thư cao hơn gấp 2 lần so với người không hút thuốc. Bên cạnh đó rượu cũng là 1 nguyên nhân lớn làm tắng nguy cơ mắc bệnh ung thư miệng. Theo tác giả tỷ lệ nam mắc ung thư biểu mô khoang miệng có uống rượu là $76,4 \%$. Sự kết hợp của hút thuốc và uống rượu càng làm nguy cơ mắc ung thư miệng tăng cao hơn. Trong nghiên cứu của chúng tôi trên 61 bệnh nhân ung thư khoang miệng cho thấy tỷ lệ bệnh nhân liên quan đến hút thuốc chiếm $60.6 \%$; uống rượu $55.7 \%$, trong đó cả uống rượu và hút thuốc là $47.5 \%$, tỷ lệ mắc giữa nam và nữ là $3 / 1$. Nếu chỉ tính nam giới thì tỷ lệ ung thư liên quan đến thuốc lá, rượu và cả thuốc lẫn rượu là rất cao, lần lượt là $80.43 \%, 73.9 \%$ và $63.04 \%$. Kết quả nghiên cứu của chúng tôi không khác biệt với các tác giả trong và ngoài nước, điều này lý giải các thói quen sinh hoạt không lành mạnh như hút thuốc, uống rượu, ăn trâuu là nguyên nhân chính dẫn tới ung thư khoang miệng nói riêng và đầu cổ nói chung.
Đặc điểm giải phẫu khoang miệng được che phủ chủ yếu bằng lớp niêm mạc mềm mại có nhiều tuyến nước bọt phụ kèm theo giúp khoang miệng luôn ướt và mềm mại. Ung thư khoang miệng thường gặp là dạng ung thư biểu mô tế bào vảy, theoKing $T$ (2010)[3]ung thư biểu mô tế bào vẩy chiếm $80 \%$ đến $90 \%$ ung thư khoang miệng. Trong nghiên cứu này chúng tôi ung thư biểu mô tế bào vảy gặp ở $100 \%$ các trường hợp và vị trí tổn thương hay gặp nhất ở lưỡi và sàn miệng,chiếm 78,7\%. Khối u xâm lấn từ nông xuống sâu, sau vị trí lưỡi và sàn miệng tổn thương hay gặp tiếp đó là lợi ổ răng và thâm nhập vào xương hàm. Sự xâm lấn của ung thư biểu mô thường đi theo chiều sâu nên ít gặp hơn ung thư ở các vùng má và môi.

Các triệu chứng lâmsàng thường xuất hiện muộnvà không điển hình, ở giai đoạn sớm các dấu hiệu lâm sàng mờ nhạt, thường là những mảng bám cứng trắng (bạch sản) hay các đám màu đỏ nhạt (hồng sản) lau bằng gạc không hết, những vết trợt loét nhỏ, hoặc những nốt sừi nhô cao... Những dấu hiệu đó thường bị nhầm lẫn với một số bệnh lành tính của niêm mạc như nấm, virus... vì vậy bệnh nhân và những bác sĩ không có kinh nghiệm thường bỏ qua hoặc điều trị sai hướng. Cũng có những dấu hiệu như lung lay răng, viêm lợi bệnh nhân thường tới khám và điều trị răng. Có những khối u chỉ là dấu hiệu trợt loét nông trên bề mặt nhưng có xu hướng phát triển lan rộng, xâm lẩn sâu vào các cơ quan lân cận.Thường khi các triệu chứng trở nên rõ ràng hơn như loét hoại tử, đau nhiều gây khó ăn, khó nói bệnh nhẩn mới tới khám, lúc đó bệnh thường đã ở giai đoạn 2 hoặc giai đoạn 3 trở lên. Về các dấu hiệu lâm sàng, bệnh nhân thường chú ý nhiều đến những dấu hiệu đau, rát và tăng tiết nước, chiếm lần lượt $85.2 \%$ và $65.6 \%$. Những vết loét lâu liền, điểm sùi vướng cũng là nguyên nhân đưa bệnh nhân tới khám chiếm $63.9 \%$ và $57.3 \%$. Về vị trí của tổn thương, trong lô nghiên cứu chúng tôi gặp tổn thương vùng lưỡi di động nhiều hơn, trong đó rìa lưỡi $72.1 \%$, đầu lưỡi $4.9 \%$. Tiếp đến là u sàn miệng $7 / 61$ trường hợp chiếm tỷ lệ $11,47 \%$, u niêm mạc má và hậu hàm $5 / 61$ trượng hợp $(8,26 \%)$ và $2 / 61$ trường hợp $(3,27 \%)$ có khối u vùng gốc lưỡi. Jatin Shah (2020) về tỷ lệ ung thư các cơ quan khoang miệng trong giai đoạn 1985-2015 tại Hoa kỳ với $51 \%$ u lưỡi, $14 \%$ khối u vùng sàn miệng, $6 \%$ khối u vùng tam giác hậu hàm và $7 \%$ là các khối u vùng niêm mạc má [6].

Trong nghiên cứu của chúng tôi không có bệnh nhân nào ở giai đoạn I, số lượng bệnh 
nhân nhiều nhất ở giai đoạn II 37/61 (60,7\%) bệnh nhân, sau đó là giai đoạn III có $16 / 61$ $(26,2 \%)$ bệnh nhân và $8 / 61(13,1 \%)$ bệnh nhân ở giai đoạn IV. Nghiên cứu của Marquet năm 2008 khối u có kích thước từ 1 đến $4 \mathrm{~cm}$ chiếm $72.4 \%$, tương đương giai đoạn I và II, chỉ có $27.6 \%$ u lớn hơn $4 \mathrm{~cm}$, tương đương giai đoạn III và IV[7]. Nghiên cứu của Thankapan K năm 2011 gặp chủ yếu bệnh nhân u có kích thước từ T1 và T2 chiếm $95,8 \%[8]$. Các tác giả trên phân loại theo u theo kích thước $T$, tương đương với u có kích thức từ dưới $2 \mathrm{~cm}(\mathrm{~T} 1)$, trong khoảng 2-4 $\mathrm{cm}(\mathrm{T} 2)$ và trên $4 \mathrm{~cm}$ (T3), cách phân loại này không khác biệt nhiều so với phân loại theo giai đoạn bệnh của chúng tôi.

\section{KẾT LUÂN}

Ung thư miệng là bệnh lý phát sinh do sự biến đổi ác tính niêm mạc bao phủ trong khoang miệng với tỷ lệ mắc bệnh có chiều hướng gia tăng. Các triệu chứng lâm sàng ở giai đoạn sớm thường không được chú ý, bệnh nhân tới khám và phát hiện khi đã ở những giai đoạn muộn nêngặp nhiều khó khăn cho việc điều trị bệnh. Chỉ định điều trị ung thư miệng phụ thuộc vào giai đoạn bệnh và mức độ di căn hạch, vì vậy đối với bệnh nhân ung thư miệng cần có kế hoạch điều trị cụ thể và toàn diện cho từng bệnh nhân để có được kết quả điều trị tốt nhất.

\section{TÀI LIÊU THAM KHẢO}

1. Pablo H. Montero, Snehal G. Patel. Cancer of the oral cavity. Surg Oncol Clin N Am. 2015; 24(3):17.

2. Miranda-Filho A, Bray F. Global patterns and trends in cancers of the lip, tongue and mouth. Oral oncology. 2020 Mar;102:104551.

3. Jerjes $\mathbf{W} .$, et al., (2010). Research Clinicopathological parameters, recurrence, locoregional and distant metastasis in $115 \mathrm{~T} 1-\mathrm{T} 2$ oral squamous cell carcinoma patients. Head \& Neck Oncology 2010. 2(9): p. 21.

4. Xiao-meng Song and Jin-hai Ye, Radial forearm free flap for reconstruction of a large defect after radical ablation of carcinoma of the tongue and floor of the mouth - some new modifications. Journal for OtoRhinoLaryngology, 2010. 72: p. 7.

5. King T, Agulnik M.(2010). Head and neck cancer: Changing epidemiology and Public health implications. Oncology Journal, Vol 24,10:1-6.

6. Shah J. P. and Gil Z., Current concepts in management of oral cancer--surgery. Oral Oncology, 2009. 45(4-5): p. 394-401.

7. Faria M.J.C., et al., The versatility of the free lateral arm flap in head and neck soft tissue reconstruction: clinical experience of 210 cases. Journal of Plastic Reconstructive Aesthetic Surgery, 2008. 61(2): p. 172-179.

8. Thankappan K., et al., Lateral arm free flap for oral tongue reconstruction: an analysis of surgical details, morbidity, and functional and aesthetic outcome. Annals of Plastic Surgery, 2011. 66(3): p. 261-166.

\title{
ĐÁNH GIÁ ĐẶC ĐIỂM GIẢI PHẪU NHÁNH TRÁN ĐộNG MẠCH THÁI DƯƠ'NG NÔNG Ở NGƯỜI VIẸTT TRƯỞNG THÀNH
}

\author{
Ngô Thế Mạnh*, Vũ Ngọc Lâm**, Lê Đức Tuấn*
}

\section{TÓM TẮT}

Mục tiêu: Đánh giá đặc điểm giải phẫu nhánh trán động mạch thái dương nông (ĐMTDN) ở người Việt trưởng thành. Đối tượng và phương pháp: Mô tả cắt ngang bằng phẫu tích 31 tiêu bản nửa đâuu của 16 xác. Kết quả và kết luận: $83,8 \%$ trường hợp ĐMTDN phân nhánh tận phía trên gò má - cung tiểp. Nguyên ủy của ĐM trển hệ trục tọa độ, cách trục Ox $33,11 \pm 10,86 \mathrm{~mm}$ và cách trục Oy khoảng 16,04 \pm $8,97 \mathrm{~mm}$. Có $35,5 \%$ số trường hợp điểm này nằm trong một hình chữ nhật đứng, kích thước 20 x 30 mm. Góc TB giữa nhánh trán với ĐMTDN là 118,81 \pm

*Bệnh viện Quân y 103

**Bênh viên TUQQĐ 108

Chịu trách nhiệm chính: Ngô Thế Mạnh

Email: ntmanhdoctor@gmail.com

Ngày nhận bài: 15/10/2021

Ngày phản biện khoa học: 18/11/2021

Ngày duyệt bài: 16/12/2021
53,47 độ. Góc giữa nhánh trán và gò má cung tiếp trung bình là $40,5^{\circ}$. Chiều dài TB thân nhánh trán là $69,78 \pm 27,93 \mathrm{~mm}$. Tại nguyên ủy, nhánh trán có ĐK TB là 2,19 $\pm 0,5 \mathrm{~mm}$. Nhánh trán sau 1 xuất hiện là $96,77 \%$, nhánh trán sau 2 chiếm tỷ lệ $61,29 \%$. Nhánh trán giữa xuất hiện chiếm $80,65 \%$. Nhánh trán trước chiếm $83,87 \%$ tiêu bản. Chiêu dài trung bình của nhánh trán sau 1 , nhánh trán sau 2 , nhánh giữa và nhánh trước lần lượt là 49,39 $\pm 21,78 ; 48,42 \pm 25,92$; $40,03 \pm 21,49 ; 28,17 \pm 11,30$ mm. Góc với ĐM trán của nhánh trán sau 1 , nhánh trán sau 2 , nhánh giữa và nhánh trước lần lượt là: 80,47 \pm 23,05; 79,47 $\pm 16,49$; $112,88 \pm 43,95 ; 109,52 \pm 30,06$ độ. Nhánh trán tận hết bằng dạng I chiếm 38,7\% và dạng II 48,4\%.

Tứ khóa: Nhánh trán động mạch thái dương nông
SUMMARY
SURVEY ON ANATOMICAL CHARACTERISTICS OF THE SUPERFICIAL TEMPORAL ARTERY FRONTAL BRANCH IN ADULT VIETNAMESE
Objective: To evaluate anatomical characteristics 